\title{
Analyzing soil contamination status in garage and auto mechanical workshops of Shashemane City: implication for hazardous waste management
}

\author{
Getachew Demie*
}

\begin{abstract}
Background: Historically human being exist in harmony with their environment. However, the current rapid urbanization, industrialization and expansion of different economic activities were lead to contamination of environmental resources. Hence, the aim of this study was determining the level of heavy metal contamination of soil in garage and auto-mechanical workshops and comparing with existing national and international standards so as to now the impact they had on human being and environment.

Methods: To achieve objectives, a total of 36 soil sample were collected form 0-15, 15-30 and 30-45 cm soil depth using calibrated auger. Three control soil samples were also collected from undisturbed area for comparison of the result so as to know the level of pollution. The concentration of heavy metal in soil samples were determined using atomic absorption spectrometer and calculation of their contamination factor, geo-accumulation index and pollution load index were done using SPSS version 20.0. To check variability of the pollutant under different service year of garage and soil depth, correlation analysis and analysis of variance were tested at $\alpha$ (alpha) $=0.05$ significance level.

Results: The result of study showed that the overall mean concentrations of the heavy metals viz. chromium (Cr), lead (Pb), nickel (Ni), cadmium (Cd) and cobalt (CO) were 290.1, 782.1, 443.6, 133.1 and 331.0 ppm respectively which is extremely higher than US EPA and EU regulation standards.

Conclusion: The value of contamination factor and degree of contamination indicated that the study area is considerably polluted by heavy metals under investigation and hence require urgent remedial action for its reclamation.
\end{abstract}

Keywords: Soil contamination, Contamination factor, Degree of contamination, Geoaccumulation index

\section{Introduction \\ Background}

Historically human beings live in harmony with their natural environment. However, the current rapid rate of industrialization and urbanization (Jiang et al. 2013) and economic activities like mining (Navarro et al. 2008), agriculture (Vaalgamaa and Conley 2008; Syed et al. 2012), industries and transportation (Jaradat et al. 2005;

\footnotetext{
*Correspondence: gech.demie1987@gmail.com

Hawassa University Wondo Genet College of Forestry and Natural Resources, School of Natural Resources and Environmental Studies, 128 Shashemane, Ethiopia
}

David and Sunday 2012) leads to contamination of environmental resources due to huge amount of waste they generate. For instance, gasoline, battery manufacture, metal plating, smelting, tanneries, petroleum refining, paint manufacture, pesticide, cosmetics, ceramics, pigment manufacture, printing and photographic industries, etc., are sources of heavy metal such as cadmium, zinc, copper, nickel, lead, mercury, cobalt, manganese and chromium (Kadirvelu et al. 2001; Alloway 1995). Furthermore, automobiles' used oil, weared machinery, used batteries, organic and inorganic chemicals used in oil as additives were also release different heavy metals (EEA 2007) and these heavy metals enter the human being and

\section{Springer}

(c) 2015 Demie. This article is distributed under the terms of the Creative Commons Attribution 4.0 International License (http:// creativecommons.org/licenses/by/4.0/, which permits unrestricted use, distribution, and reproduction in any medium, provided you give appropriate credit to the original author(s) and the source, provide a link to the Creative Commons license, and indicate if changes were made. 
environment through biomagnifications in food chains (Bradl 2005), ingestion, skin absorption, inhalation of volatile heavy metals, leaching, runoff, deposition of atmospheric particulate, disposal of metal enriched sewage sludges and effluents. Once entered food chain and ecosystem, heavy metals have capacity to pose a wide range of adverse health and environmental problems (Tamene 2008; Cai et al. 2011). For instance the study of Adela et al. (2012) confirmed that garage and automotive workers were in danger of impending lead toxicity and facing abdominal colic, constipation, fatigue and central nervous system dysfunction.

The study of Naser et al. (2011) and Itanna (2002) also confirmed that plants and leafy vegetables grown using wastewater and polluted soil can accumulate toxic heavy metals above maximum limit stated by FAO (1985) and USEPA (www.EPA.Gov.) causing serious risk to human health when consumed (Akinola et al. 2008). Generally, toxic metals cause enzyme inactivation, acute mental lapse (lead), kidney, liver, gastrointestinal tract (cadmium) and central nervous system damage (arsenic) (Landrigan 1994 cited in Adela et al. 2012).

Currently, the Shashemane City is characterized as one of the fastest growing city and center of business in Oromia region. Besides this, the number of garages are rapidly increasing and an individual may get garage in maximum of $1 \mathrm{~km}$ interval while is enjoying in the city. This implies that the, whether it is large or small scale garage, it releases different types of pollutant that have significant potential impact to environment (soil, water and air) (Adie and Osibanjo 2009; Olukanni and Adeoye 2012; Ololade 2014) undertaking different operational activities. These metals are none biodegradable and deposit themselves in environment resources and cause pollution. This was also the major challenges in Shashemane City due to absence of appropriate hazardous waste management and less emphasis given to garage and auto mechanical waste. To reverse the situations and inform concerned body, chemical analysis of soil and research are mandatory. However, there has not been agreed guidance and researches conducted on the heavy metal contamination of soils due to waste released form garages and auto mechanical workshops. Even the research studies conducted at different area were not directly related to garage waste and not complete rather specific to single types of metals while others depend on the source and types of waste. For instance, the Adela et al. (2012) focus on impact of exposure to lead by garage workers while the study of Itanna (2002) was about contamination of vegetables by wastewater; soil pollution by solid waste disposal sites Hunachew and Sandip (2011). Hence the objective of this research is to analyze soil pollution status in garage and auto mechanical workshops and compare the result with national and international standard.

\section{Methods}

\section{Description of study area}

Shashemane City is one of the largest developing city found in Oromia regional state, west Arsi zone, and located $250 \mathrm{~km}$ south of the capital Addis Ababa. It had geographical location between $7^{\circ} 12^{\prime}$ latitudes north and $38^{\circ} 36^{\prime}$ longitudes east (Fig. 1). The area lies within the Rift valley with altitudes ranging from 1700 to $2600 \mathrm{~m}$ above sea level. It receives an annual rainfall of 700-950 $\mathrm{mm}$ and has an annual temperature range of 12-17 ${ }^{\circ} \mathrm{C}$ (SWARDO 2006). Major crops grown around Shashemane area are cereals such as teff, barley, wheat, maize, sorghum and root crops like potato and sweet potato and vegetables such as cabbage, spinach and onion as cash crops. Annual crops are predominant and rain-fed agriculture is mainly practiced. The total human population of this area is 100,454 of whom 50,654 were men and 49,800 were women (CSA 2007).

\section{Sampling and analytical procedures}

A total of 39 (36 from garage and 3 as control) composite soil samples were collected purposively from 12 garage and auto-mechanic workshops in Shashemane City on the basis of the age of establishment of garage and auto mechanical workshops. Age of garage and auto mechanical workshops is one of the factors affecting the heavy metal pollution level of soil resources. Hence, garage and workshops that account age more than 3 years were considered and soil samples were collected from depths of $0-15,15-30$ and $30-45 \mathrm{~cm}$ using a depth calibrated soil auger. The sampler was inspected for possible crosscontamination and cleaned with ambient water for individual sample collection. Each sample were immediately placed in plastic bag and tightly sealed to avoid contamination form environment. Collected soil samples were air dried for several days in soil sample preparation room in Wondo Genet College of Forestry and Natural Resources. Then $2-3 \mathrm{~g}$ dry soil samples were digested in about $15 \mathrm{ml}$ of aqua-regia $\left(\mathrm{HCl}: \mathrm{HNO}_{3}=3: 1\right)$ for approximately $4-5 \mathrm{~h}$ at temperature of approximately $110^{\circ} \mathrm{C}$ followed by diluting the sample using distilled water of about $50 \mathrm{ml}$ in a $100 \mathrm{ml}$ Pyrex glass beaker. After filtering the solution, the filtrates were analyzed using atomic absorption spectrophotometer (AAS) at Ethiopian Environmental Protection Authority soil laboratory. Flame atomic absorption spectrophotometer was used for determining the concentration of $\mathrm{Ni}, \mathrm{Cr}, \mathrm{Cd}$ and $\mathrm{CO}$ while graphite furnace AAS was used for lead $(\mathrm{Pb})$ analysis. The soil organic carbon was determined using Walkley and Black's method (Allison 1986). After collection of all the necessary 


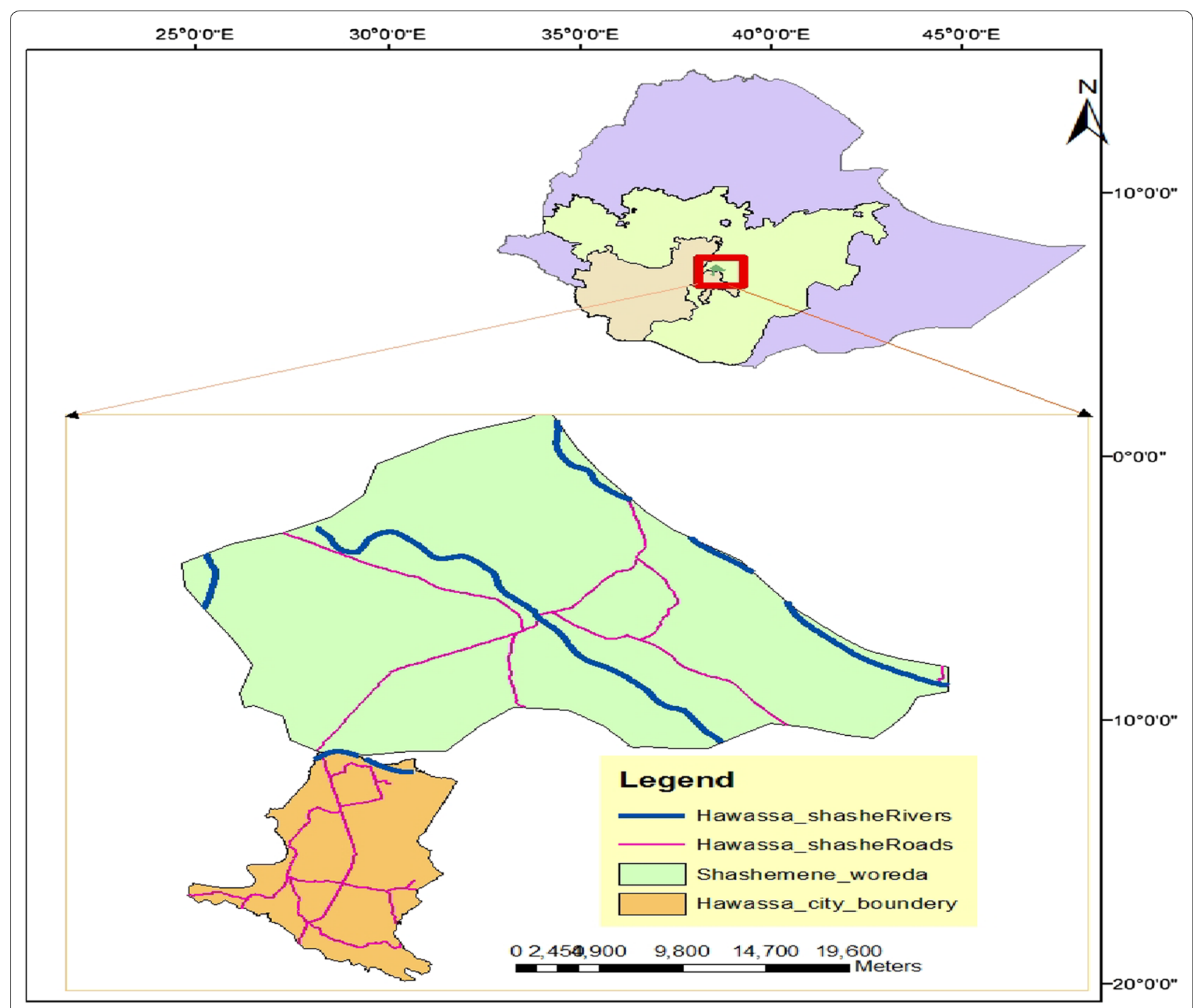

Fig. 1 Location of the study area

data, further data analysis (ANOVA, correlation and regression analysis) were conducted using Statistical Package for Social Science (SPSS) of version 20.0. Geoaccumulation index (Muller 1969), contamination factor and degree of contamination (Hakanson 1980), modified degree of contamination and pollution load index (Tomlinson et al. 1980) of the pollutant were also calculated using the following equations.

$$
I_{\text {geo }}=\log _{2} \frac{C_{n}}{1.5 B_{n}}
$$

where $I_{\text {geo }}$ is geoaccumulation index of the metal; $C_{n}$ is the measured concentration of the element in the sample and $B_{n}$ is the geochemical background value. The constant 1.5 allows us to analyze natural fluctuations in the content of the given substance in the environment as well as very small anthropogenic influences.

$$
\mathrm{C}_{\mathrm{f}}^{\mathrm{i}}=\frac{\mathrm{C}_{\mathrm{o}}^{\mathrm{i}}}{\mathrm{C}_{\mathrm{n}}^{\mathrm{i}}}
$$

where, $C_{f}^{i}$ is the contamination factor for the element I; $\mathrm{C}_{\mathrm{o}}^{\mathrm{i}}$ is the mean content of metal from at least five sampling sites and $C_{n}^{i}$ is the concentration of the individual metal in control.

The sum of individual contamination factor of the pollutant will give degree of contamination (Hakanson 1980). Hence, degree of contamination $\left(C_{d}\right)$ is computed by the following equation: 


$$
\mathrm{C}_{\mathrm{d}}=\sum_{\mathrm{i}=1}^{\mathrm{n}} \mathrm{Cf}^{\mathrm{i}}
$$

where $\mathrm{Cf}^{\mathrm{i}}$ is the contamination factor of each metals; $\mathrm{n}$ is the number of heavy metals under investigation.

The degree of contamination is aimed at providing a measure of the degree of overall contamination in surface layers in particular sampling site. Abrahim and Parker (2008) presented a modified and generalized form of the Hakanson (1980) equation for the calculation of the overall degree of contamination at a given sampling or coring site and this was used in this study.

$$
\mathrm{mC}_{\mathrm{d}}=\frac{\sum_{\mathrm{i}=1}^{\mathrm{n}} \mathrm{Cf}^{\mathrm{i}}}{\mathrm{n}}
$$

where, ${ }_{m} C_{d}$ is modified degree of contamination, $n$ is the number of analyzed element and $\mathrm{C}_{\mathrm{f}}^{\mathrm{i}}$ is the contamination factor.

The pollution load index which was proposed by Tomlinson et al. (1980) was also calculated for comparison of pollution level between sites and propose necessary action that should be taken. It was obtained as a concentration factor of each heavy metal with respect to the background value in the soil.

$$
\text { PLI }=\sqrt[n]{\mathrm{cf}_{1} * \mathrm{cf}_{2} * \ldots \ldots * \mathrm{cf}_{\mathrm{n}}}
$$

where $\mathrm{n}$ is the number of heavy metals under investigations; $\mathrm{Cf}_{1}$ is contamination factor of metal one; $\mathrm{Cf}_{2}$ contamination factors of metal two; $\mathrm{Cf}_{\mathrm{n}}$ is contamination factors of metal $n$.

According Tomlinson et al. (1980), a pollution load index $(\mathrm{PLI})<1$ denote perfection; PLI $=1$ present that only baseline levels of pollutants are present and PLI $>1$ would indicate deterioration of site quality.

\section{Result and discussion}

\section{Chemical concentration of studied element}

The organic matter content of the soil determines its quality (Komatsuzaki and Ohta 2007). The mean organic matter content of the soil within study area was about $48.8 \pm 11.5$ and it vary in their concentration between samples (Table 1) and across the three soil sampling depth (Fig. 2). Most of the soil samples under investigation had less organic matter and show a decreasing trend across soil depth. Similarly, the result of Pearson correlation analysis (Edwards 1976) indicated that there is negative correlation between the depth and soil organic matter content as in Table 2. This might be due to continuous compaction of the area by cars and disposal of toxic pollutant that create unfavorable environment for soil microorganisms.

The $\mathrm{pH}$ of the soil, which is an important parameter that directly influences mineral mobility, is also varying from 0.4 to 3.4 at study area. This characterizes the soil to be too acidic in the area. The $\mathrm{pH}$ and electrical conductivity of soil were also vary across the sample and sampling depth. These may be due to the manipulation and disturbance made by human activity within the garages (Allison 1986).

$\%$ Soil organic matter $=\%$ organic carbon $* 1.724$

The mean concentrations of the heavy metals were varying per sample and within the study area. As indicated in Table 1 , the concentration of chromium $(\mathrm{Cr})$, lead

\begin{tabular}{|c|c|c|c|c|c|c|c|c|}
\hline Sample & $\mathrm{Cr}$ & $\mathrm{Pb}$ & $\mathrm{Ni}$ & $\mathrm{Cd}$ & $\mathrm{CO}$ & $\mathrm{pH}$ & SOM (\%) & $E C(\mu S)$ \\
\hline 1 & 168.7 & 613.4 & 390 & 84.9 & 845.5 & 0.4 & 35.3 & 1007.2 \\
\hline 2 & 263.1 & 382.5 & 1086.6 & 307.8 & 1685.7 & 0.6 & 19.7 & 1018.3 \\
\hline 3 & 125.1 & 236.4 & 390 & 230.7 & 164.9 & 3.4 & 16.9 & 688.2 \\
\hline 4 & 82.8 & 526.4 & 679.9 & 81.4 & 131 & 0.4 & 34.2 & 929.6 \\
\hline 5 & 207 & 192.2 & 408.1 & 14.7 & 156.1 & 0.6 & 19 & 1000.6 \\
\hline 6 & 230.5 & 791 & 18.9 & 185.9 & 117.3 & 0.5 & 15.8 & 656.8 \\
\hline 7 & 128.1 & 742.2 & 10.8 & 119 & 165.8 & 0.4 & 34 & 922.9 \\
\hline 8 & 1003.7 & 681.8 & 197.3 & 120.9 & 157.1 & 0.6 & 19.2 & 1006.5 \\
\hline 9 & 243 & 587.9 & 42.8 & 128.7 & 137.8 & 0.5 & 16.3 & 675.3 \\
\hline 10 & 450.7 & 468.9 & 787.1 & 87.4 & 179 & 0.3 & 34.4 & 950.1 \\
\hline 11 & 391.6 & 3041.3 & 1044 & 144.3 & 72.2 & 0.6 & 19.6 & 994 \\
\hline 12 & 186.4 & 1121 & 268.2 & 91.9 & 159.6 & 0.4 & 15.7 & 694.2 \\
\hline Mean $\pm S D$ & $290.1 \pm 248.8$ & $782.1 \pm 754.7$ & $443.6 \pm 378.3$ & $133.1 \pm 77.5$ & $331.0 \pm 472.7$ & $1.1 \pm 1.5$ & $48.8 \pm 11.5$ & $904.6 \pm 557.5$ \\
\hline Range & $82.8-1003.7$ & $192.2-3041.3$ & 10.8-1086.6 & $14.7-307.8$ & $72.2-1685.7$ & $0.3-3.4$ & $15.7-35.3$ & 656.8-1018.3 \\
\hline Control & 188.05 & 8.45 & 20.06 & 10.5 & 53.11 & -0.75 & 214.17 & 3.5 \\
\hline
\end{tabular}
$(\mathrm{Pb})$, nickel $(\mathrm{Ni})$, cadmium $(\mathrm{Cd})$ and cobalt $(\mathrm{CO})$ were

Table 1 Average heavy metal concentration in $\mathrm{mg} \mathrm{kg}^{-1}$ per sample within study area 


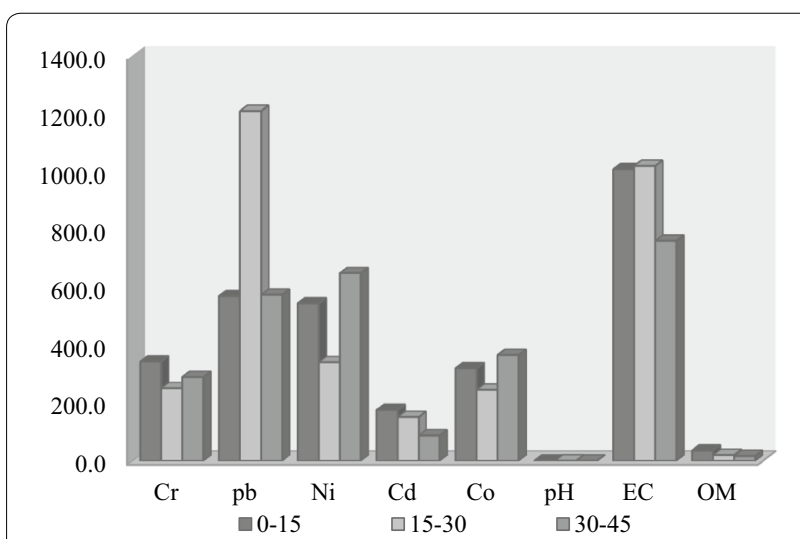

Fig. 2 Depth wise variation of average heavy metal concentration (in $\mathrm{mg} \mathrm{kg}^{-1}$ ) within study area

290.1, 782.1, 443.6, 133.1 and $331.0 \mathrm{mg} \mathrm{kg}^{-1}$ respectively. Accordingly, the trend of metals on the basis of their mean concentration was: $\mathrm{Pb}>\mathrm{Ni}>\mathrm{CO}>\mathrm{Cr}>\mathrm{Cd}$. The variation of heavy metals mean concentration was also observed across the different soil sampling depth as indicated in Fig. 2. These indicate that the concentration of lead is relatively very high compared to the other heavy metals within study area. This was in line with the finding of Endale et al. (2012) at Addis Ababa City. The possible reason for high concentration of lead within study area might be in appropriate use and disposal of leaded gasoline, body repair activity using metal welding and other garage wastes.

The variation of heavy metal concentration in the study area was due to the service year of garage after their establishment. The result of person correlation analysis ( $\alpha$-alpha $=0.05$ and 0.01$)$ between heavy metal and service year of garages also showed that there is a positive relationship among them though the magnitude of their relation ranges from moderate to weak (Table 2).
However, this was not statistically significant for all metals except chromium when analyzed using one way ANOVA at $\alpha$ (alpha) $=0.05$ as in Table 3 below. The other possible reason for the variation was illegal disposal of gasoline, used batteries, metals plating sand smelting that have potential to release hazardous toxic metal to soil. This was in line with the study of Kadirvelu et al. (2001) which states that garage activities like disposal of gasoline, battery manufacture, metal plating and smelting can release heavy metal such as cadmium, nickel, lead, cobalt and chromium. According to Ololade (2014), these heavy metals were often contained as additives in lubricants and gasoline used by vehicles and hence contributed for pollution of soil due to inappropriate waste management. Land manipulation activity (like covering the garage compound with new soil from other areas) carried by garage owner due to fear of illegal activity (disposal of hazardous toxic waste) they are doing were also another source of variation of heavy metal across of samples and within soil sampling depth.

The concentration of heavy metal under investigation was relative very high when compared with other similar studies conducted in the country and outside the country (Table 4). For instance, the mean concentration of $\mathrm{Cd}(133.1 \pm 77.5)$ is relatively very high compared to the studies conducted by Itanna (2002), Itanna et al. (2008), Hunachew and Sandip (2011) and Melaku et al. (2005). Similarly, its concentration is higher than the finding of Shacklette and Boerngen (1984) and Bradford et al. (1996) conducted in USA and China respectively. It is around two fold of the standard settled by united state Environmental protection agency and 45 fold of upper limit $\left(3 \mathrm{mg} \mathrm{kg}^{-1}\right)$ specified by European regulation standards. In line with Hewitt and Rashed (1988), the source of high concentration of cadmium in this study area was metal plating, lubricating oils (grease), old tyres and

Table 2 Correlation coefficient matrix for the metals in soil in garage of Shashemane city

\begin{tabular}{|c|c|c|c|c|c|c|c|c|c|c|}
\hline & Depth & Service_year & $\mathrm{Cr}$ & $\mathrm{Pb}$ & $\mathrm{Ni}$ & $\mathrm{Cd}$ & $\mathrm{CO}$ & $\mathrm{pH}$ & EC & SOM \\
\hline Depth & 1 & & & & & & & & & \\
\hline Service_year & 0.000 & 1 & & & & & & & & \\
\hline $\mathrm{Cr}$ & -0.163 & $0.418^{*}$ & 1 & & & & & & & \\
\hline $\mathrm{Pb}$ & 0.036 & 0.327 & -0.076 & 1 & & & & & & \\
\hline $\mathrm{Ni}$ & 0.054 & $0.347^{*}$ & 0.193 & 0.069 & 1 & & & & & \\
\hline $\mathrm{Cd}$ & -0.318 & 0.104 & 0.018 & 0.079 & -0.089 & 1 & & & & \\
\hline $\mathrm{CO}$ & 0.047 & 0.209 & -0.071 & -0.175 & $0.428^{* *}$ & 0.029 & 1 & & & \\
\hline $\mathrm{pH}$ & 0.056 & -0.092 & 0.109 & 0.027 & -0.195 & 0.156 & -0.016 & 1 & & \\
\hline EC & -0.182 & 0.084 & 0.098 & 0.128 & -0.069 & 0.120 & 0.033 & 0.192 & 1 & \\
\hline SOM & $-0.605^{* *}$ & -0.103 & -0.019 & -0.003 & -0.040 & 0.110 & 0.089 & 0.028 & $0.370^{*}$ & 1 \\
\hline
\end{tabular}

${ }^{*}$ Correlation is significant at the 0.05 level (2-tailed). c. Listwise $\mathrm{N}=36$

** Correlation is significant at the 0.01 level (2-tailed) 
Table 3 ANOVA table for testing the significance of the concentration of different element with service year of garages

\begin{tabular}{|c|c|c|c|c|c|}
\hline & Sum of squares & df & Mean square & $F$ & Sig. \\
\hline \multicolumn{6}{|l|}{$\mathrm{Cr} \times$ service year } \\
\hline Between groups & $623,992.2$ & 2 & $311,996.1$ & 4.196 & 0.024 \\
\hline Within groups & $2,453,674.9$ & 33 & $74,353.8$ & & \\
\hline Total & $3,077,667.1$ & 35 & & & \\
\hline \multicolumn{6}{|l|}{$\mathrm{Pb} \times$ service year } \\
\hline Between groups & $5,026,561.8$ & 2 & $2,513,280.9$ & 2.356 & 0.111 \\
\hline Within groups & $35,202,359.9$ & 33 & $1,066,738.1$ & & \\
\hline Total & $40,228,921.8$ & 35 & & & \\
\hline \multicolumn{6}{|l|}{$\mathrm{Ni} \times$ service year } \\
\hline Between groups & $1,306,603.1$ & 2 & $653,301.568$ & 2.264 & 0.120 \\
\hline Within groups & $9,523,424.404$ & 33 & $288,588.618$ & & \\
\hline Total & $10,830,027.5$ & 35 & & & \\
\hline \multicolumn{6}{|l|}{$\mathrm{Cd} \times$ service year } \\
\hline Between groups & $39,811.9$ & 2 & $19,905.9$ & 1.737 & 0.192 \\
\hline Within groups & $378,225.7$ & 33 & $11,461.4$ & & \\
\hline Total & $418,037.6$ & 35 & & & \\
\hline \multicolumn{6}{|l|}{$\mathrm{CO} \times$ service year } \\
\hline Between groups & $338,752.4$ & 2 & $169,376.2$ & 0.877 & 0.426 \\
\hline Within groups & $6,375,158.8$ & 33 & $193,186.6$ & & \\
\hline Total & $6,713,911.2$ & 35 & & & \\
\hline \multicolumn{6}{|l|}{$\mathrm{pH} \times$ service year } \\
\hline Between groups & 2.5 & 2 & 1.2 & 1.198 & 0.315 \\
\hline Within groups & 34.2 & 33 & 1.0 & & \\
\hline Total & 36.7 & 35 & & & \\
\hline \multicolumn{6}{|l|}{ EC $\times$ service year } \\
\hline Between groups & $310,882.3$ & 2 & $155,441.1$ & 0.485 & 0.620 \\
\hline Within groups & $10,565,662.0$ & 33 & $320,171.6$ & & \\
\hline Total & $10,876,544.3$ & 35 & & & \\
\hline \multicolumn{6}{|l|}{ SOM $\times$ service year } \\
\hline Between groups & 115.7 & 2 & 57.9 & 0.422 & 0.659 \\
\hline Within groups & 4525.7 & 33 & 137.1 & & \\
\hline Total & 4641.4 & 35 & & & \\
\hline
\end{tabular}

hazardous waste disposed in and around garage. This leads to several health hazard like kidney and bone damage, cancer risk and increased mortality when exposed to polluted soil (Jarup and Akesson 2009).

The mean concentration of lead $\left(782.1 \pm 248.8 \mathrm{mg} \mathrm{kg}^{-1}\right)$, nickel (443.6 $\left.\pm 378.3 \mathrm{mg} \mathrm{kg}^{-1}\right)$ and cobalt $\left(331.0 \pm 472.7 \mathrm{mg} \mathrm{kg}^{-1}\right)$ are also very high compared to studies conducted by Itanna et al. (2008); Hunachew and Sandip (2011); and Melaku et al. (2005) in Ethiopia. It is also extremely higher than maximum tolerable standard of USEPA (1993) and European regulation standards (Ewers 1991) as in Table 4. The highest concentration of lead observed in study area is most likely from vehicle emissions and leaded gasoline combustion. As pin pointed by
Atuanya and Oseghe (2006), higher lead concentration in soils has toxic effect on soil microorganisms which can in turn influence the presence of flora and fauna. It also leads to impaired mental and physical development, liver and kidney damage, brain and central nervous system damage, decreased hemi biosynthesis and serum levels of vitamin D in children (Needleman et al. 1990).

The chromium concentration relatively elevated compared to the finding of Itanna (2002) in soil sample taken from adjacent Bulbula and Kera river of Addis Ababa City and European regulation standards. However, it is lower than the united state environmental protection agency standards (1993). In general, the area is extremely polluted by toxic metals under investigation and requires urgent response.

\section{Index of geoaccumulation $\left(I_{\text {geo }}\right)$}

The geoaccumulation index $\left(\mathrm{I}_{\text {geo }}\right)$ was used to evaluate the heavy metal pollution by comparing current concentrations with reference (control) values. The results of sampling point wise geoaccumulation index value and contamination levels of different heavy metals in the soil of study area were given in Fig. 3. According to Muller (1969), this index consists of seven scales (0-6) ranging from unpolluted to very highly polluted. These seven descriptive classes were: $<0$ which imply practically uncontaminated; $0-1=$ uncontaminated to slightly contaminated; $1-2=$ moderately contaminated; $2-3=$ moderately to highly contaminated; $3-4=$ highly contaminated; $4-5=$ highly to very highly contaminated and $>5$ very highly contaminated. The interpretation of the result was made based on this scale in comparison with control/refers sample.

The result of data analysis showed that the $I_{\text {geo }}$ was distinctively variable and suggests that soil in garages of Shashemane City ranged from uncontaminated to extremely contaminated with respect to the analyzed heavy metals. $\mathrm{I}_{\text {geo }}$ revealed that except sample 8, 10 and 11 (which falls in class 1 -uncontaminated/moderately contaminated), the remaining sampling points were falling in Class $\mathrm{O}$ (uncontaminated) with respect of chromium and sampling point 6 and 7 for nickel. In case of lead, among the 12 sampling point 8 of them were falling under extremely contaminated class. This high index is caused mainly by inappropriate disposal of hazardous waste like used oil and metallurgical activity.

\section{Contamination factor, degree of contamination, modified degree of contamination and pollution load index}

Soil in the study area were also assessed for contamination factors, degree of contamination, modified degree of contamination and the pollution load index, and the result are given in Table 5. The interpretation of the 
Table 4 Comparing the value of heavy metals in study area with other studies in the country and outside the country including standards

\begin{tabular}{|c|c|c|c|c|c|c|c|c|c|}
\hline \multirow[t]{2}{*}{ Metal } & \multirow[t]{2}{*}{ This study } & \multicolumn{4}{|c|}{ Study in Ethiopia (in $\mathrm{mg} \mathrm{kg}^{-1}$ ) } & \multicolumn{2}{|c|}{$\begin{array}{l}\text { Study in other county (in } \\
\mathrm{mg} \mathrm{kg}^{-1)}\end{array}$} & \multirow[t]{2}{*}{$\begin{array}{l}\text { USEPA stand } \\
\left(\mathrm{mg} \mathrm{kg}^{-1}\right)^{\mathrm{f}}\end{array}$} & \multirow[t]{2}{*}{$\begin{array}{l}\text { EU Reg } \\
\left(\mathrm{mg} \mathrm{kg}^{-1}\right)^{\mathrm{g}}\end{array}$} \\
\hline & & Bulbula $^{a}$ & Kera $^{a}$ & Addis Ababa City & Tinishu Akakic & USA study ${ }^{d}$ & China study & & \\
\hline $\mathrm{Cd}$ & $14.7-307.8$ & 0.71 & 0.44 & $0.56-5.9$ & $0.12-1.61$ & NA & $0.02-0.33$ & 85 & 3 \\
\hline $\mathrm{CO}$ & $72.2-1685.7$ & 27.95 & 43.00 & $25-34$ & NA & NA & NA & $0.3-200$ & 50 \\
\hline $\mathrm{Cr}$ & $82.8-1003.7$ & 81.00 & 115 & $70-561$ & $86.3-15790$ & $6.59-208$ & $19.3-150$ & 3000 & 100 \\
\hline $\mathrm{Ni}$ & $10.8-1086.6$ & 74.13 & 115 & $33-46$ & $47.3-200.6$ & $2.44-69.4$ & $7.73-70.9$ & 75 & 50 \\
\hline $\mathrm{Pb}$ & 192.2-3041.3 & 46.74 & 110 & $17-852$ & $20.3-325.4$ & $4.62-55.4$ & $9.95-56.0$ & 420 & 100 \\
\hline
\end{tabular}

NA not available

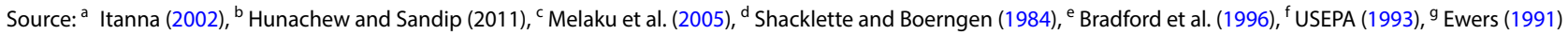

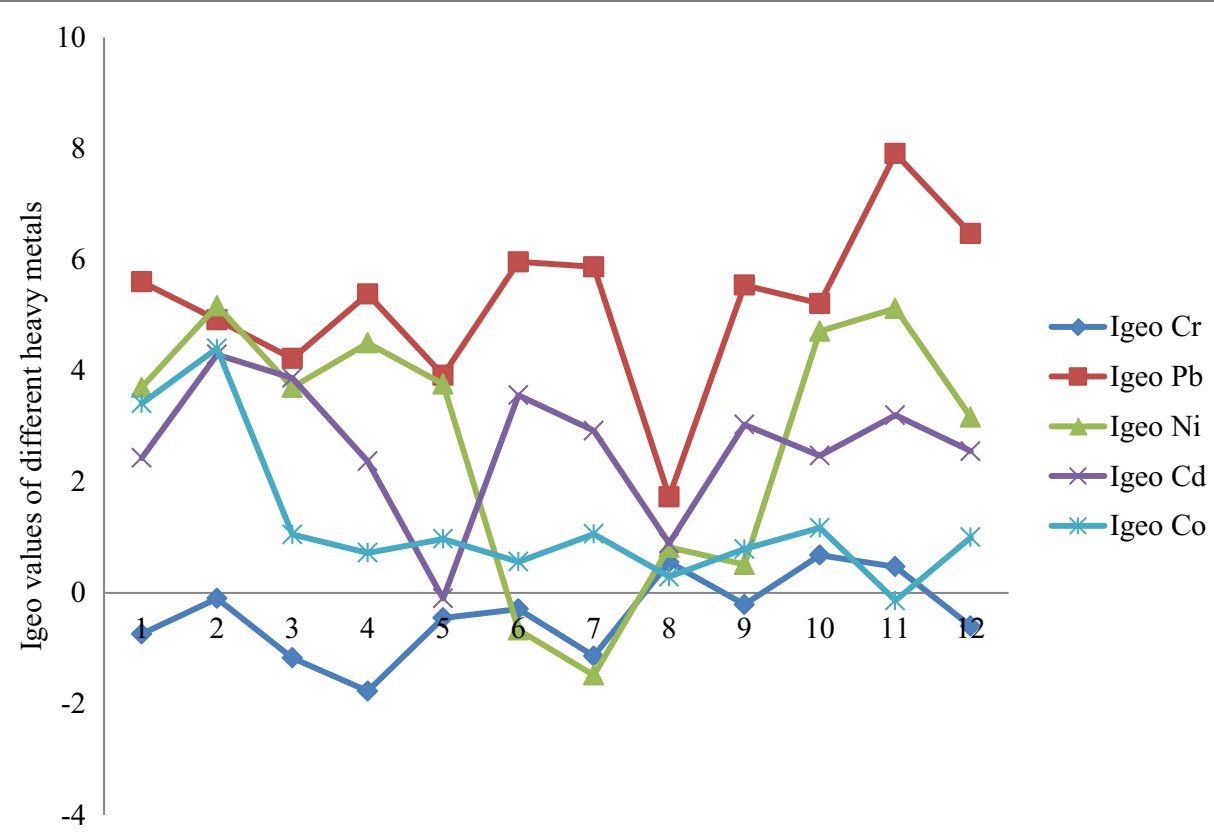

Fig. 3 Sample wise index of geoaccumulation for contamination levels of soil in garages

Table 5 Contamination factors, degree of contamination, modified degree of contamination and pollution load index of the five elements studied within study area

\begin{tabular}{lrllll}
\hline Sample no. & \multicolumn{1}{c}{$\mathbf{C r}$} & $\mathbf{P b}$ & $\mathbf{N i}$ & $\mathbf{C d}$ & $\mathbf{C O}$ \\
\hline $\mathrm{C}_{\mathrm{f}}$ & 1.54 & 92.55 & 22.12 & 12.68 & 6.23 \\
$\mathrm{C}_{\mathrm{d}}$ & 135.13 & & & & \\
${ }_{\mathrm{m}} \mathrm{C}_{d}$ & 27.03 & & & & \\
$\mathrm{PLI}$ & 1.93 & & & & \\
\hline
\end{tabular}

result was made based on descriptive scales developed by Hakanson (1980) and Abrahim and Parker (2008) as given in Tables 6 and 7.
Table 6 Contamination factors and degree of contamination categories with their terminologies for description

\begin{tabular}{llll}
\hline S.n. & $\mathbf{C}_{\mathbf{f}}$ classes & $\mathbf{C}_{\mathbf{f}}$ and $\boldsymbol{C}_{\mathbf{d}}$ terminologies & $\boldsymbol{C}_{\mathbf{d}}$ classes \\
\hline 1 & $C_{\mathrm{f}}<1$ & $\begin{array}{l}\text { Low } C_{\mathrm{f}} \text { indicating low contamination/ } \\
\text { low } C_{d}\end{array}$ & $C_{d}<8$ \\
2 & $1 \leq C_{f}<3$ & Moderate $C_{f} /$ moderate $C_{d}$ & $8 \leq C_{d}<16$ \\
3 & $3 \leq C_{f}<6$ & Considerable $C_{f} / C_{d}$ & $16 \leq C_{d}<32$ \\
4 & $C_{f} \geq 6$ & Very high $C_{f} / C_{d}$ & $C_{d} \geq 32$ \\
\hline \multicolumn{3}{l}{ Source: }
\end{tabular}

The assessment of soil contamination was carried out using the contamination factor and degree of contamination based on four classification categories proposed 
Table 7 Modified degree of contamination classification and their description

\begin{tabular}{lll}
\hline S.n. & ${ }_{\mathbf{m}} \boldsymbol{C}_{\mathbf{d}}$ classes & Description \\
\hline 1 & ${ }_{\mathrm{m}} \mathrm{C}_{\mathrm{d}}<1.5$ & Nil to very low degree of contamination \\
2 & $1.5 \leq{ }_{\mathrm{m}} \mathrm{C}_{\mathrm{d}}<2$ & Low degree of contamination \\
3 & $2 \leq_{\mathrm{m}} \mathrm{C}_{\mathrm{d}}<4$ & Moderate degree of contamination \\
4 & $4 \leq{ }_{\mathrm{m}} \mathrm{C}_{\mathrm{d}}<8$ & High degree of contamination \\
5 & $8 \leq{ }_{m} C_{d}<16$ & Very high degree of contamination \\
6 & $16 \leq{ }_{m} C_{d}<32$ & Extremely high degree of contamination \\
7 & ${ }_{\mathrm{m}} \mathrm{C}_{\mathrm{d}} \geq 32$ & Ultra high degree of contamination \\
\hline
\end{tabular}

Source: Abrahim and Parker (2008)

by Hakanson (1980) while seven classification categories recognized by Abrahim and Parker (2008) were used for modified degree of contamination classification and description as presented in Tables 6 and 7 respectively.

Based on the contamination factor values, the overall contamination of soils within study area were moderately contaminated by chromium and very highly contaminated by lead, nickel, cadmium and cobalt. The result of modified degree of contamination also indicates that the study area is extremely contaminated. This may be due to different activities viz. dewaxing and cleaning of vehicles; the storage, use and disposal of polluting liquids such as oils, paints, solvents, antifreeze and other coolant additives, brake fluids and solid waste such as oil filters, exhaust systems, batteries and tyres taking place within garage and auto-mechanical workshops. In order to minimize the effect of spikes of individual elements and to have accurate interpretation of the ${ }_{m} C_{d}$ result, the calculation of pollution load index was carried out and its result reveals that the soil quality of study area were deteriorated. Thus urge for immediate interventions to ameliorate the pollution within study area.

\section{Correlation matrix}

Pearson correlation analysis (Edwards 1976) was performed between all the variables to check their interaction with one another in the study area. The level of significance $(\mathrm{P} \leq 0.05, \mathrm{p} \leq 0.01)$ of heavy metals correlation for soil samples was determined and the results were given in Table 2. The Pearson correlation ( $r$ ) values showed that there is strong negative correlation and statistically significant relation between depth of soil sample and soil organic matter within study area. There is also weak to moderate correlation between service year (year of establishment) of garage and heavy metals under investigation. For instance, chromium and nickel show positive and statistically significant relation with year of garage establishment. The correlation coefficient matrix of $\mathrm{pH}$, electrical conductivity and soil organic matter indicated extremely weak to weak relation with heavy metals under study. The metallic-metallic correlation coefficient in the soil samples with $\mathrm{p}<0.01$ was observed between cobalt and nickel metal; which indicates that they inter the soil from rechargeable batteries and repair of automobiles within garage. In other vine they come from common anthropogenic sources.

\section{Conclusion and recommendation}

Soil is the major repository of different pollutant emitted from different sources especially from anthropogenic activity and leading to deterioration of quality of soil resources. This was greatly aggravated by current rate of industrialization and urbanization that release huge amount of heavy metals to surrounding environment. Garage and auto-mechanical workshops are also another source of hazardous pollutant for soil resource and causing disruption of normal function of soil resources. Thus, the pollution of soil resource is calling for great concern though it is characterized by the problems of developed countries. The impact of soil pollution is found to be more hazardous for developing countries like Ethiopia due to lack of proper consideration and management. The wittiness for this conclusion may be allocation of trade license carried out by trade and industry bureau for garage workers here and their within vicinity of individual residences. The result of this study also proofed that garage and auto-mechanical workshops have the potential to emit huge amount of heavy metal pollutant to soil resource. This may in turn leads to several health related hazards when individuals are exposed to these polluted soil around and within garage areas. A lots of study showed, exposure to heavy metal would result in reduced oxygen flow in red blood cells, disruption of ecosystem function, increased risk of chest pain for person with heart disease and death. Therefore, in order to reduce the contamination of soil by heavy metals around garage, appropriate areas should be selected like developing garage and auto-mechanical zone, regulation and management of hazardous waste released from garage should be carried out by environmental authority and trade and industry bureau as well. Furthermore, application of phytoremediation is also required in order to reclaim extremely contaminated soils.

\section{Abbreviations}

AAS: atomic absorption spectrophotometer; ANOVA: analysis of variance; $C_{d}$ : degree of contamination; $C_{f}$ : contamination factor; df: degree of freedom; $E C$ : electrical conductivity; $I_{\text {geo }}$ : index of geoaccumulation; ${ }_{\mathrm{m}} \mathrm{C}_{\mathrm{d}}$ : modified degree of contamination; OM: organic matter; PLI: pollution load index; SPSS: Statistical Package for Social Science.

\section{Author's information}

Getachew Demie: Lecturer at Hawassa University Wondo Genet College of Forestry and Natural Resources. He mainly teaches courses related to Environmental resource management, water pollution, land degradation and 
Rehabilitation; and undertake research on Soil pollution, water accessibility and impact of open landfill.

\section{Acknowledgements}

I would like to thank Research and development office of Wondo Genet College of Forestry and Natural Resources for providing financial support to conduct this research.

\section{Compliance with ethical guidelines}

\section{Competing interest}

The authors declare that they have no competing interests.

Received: 28 July 2015 Accepted: 27 August 2015

Published online: 15 September 2015

\section{References}

Abrahim GMS, Parker RJ (2008) Assessment of heavy metal enrichment factors and the degree of contamination in marine sediments from Tamaki Estuary, Auckland, New Zealand. Environ Monit Assess 136:227-238

Adela Y, Ambelu A, Tessema D (2012) Occupational lead exposure among automotive garage workers - a case study for Jimma town. J Occup Med Toxicol, Ethiopia. doi:10.1186/1745-6673-7-15

Adie G, Osibanjo O (2009) Assessment of soil pollution by slag from an automobile battery manufacturing plant in Nigeria. Afr J Environ Sci Technol 3(9):239-250

Akinola MO, Njoku KL, Ekeifo BE (2008) Determination of lead, cadmium and chromium in the tissue of an economically important plant grown around a textile industry at Ibeshe, Ikorodu area of Lagos State, Nigeria. Adv Environ Biol 2(1):25-30

Allison LE (1986) Organic carbon. In: Klute A (ed) Methods of soil analysis, part I. American Society of Agronomy, Madison, pp 1367-1381

Alloway BJ (1995) Soil pollution and land contamination. In: Harrison RM (ed) Pollution: causes, effects and control. The Royal Society of Chemistry, Cambridge, p 318

Atuanya El, Oseghe EO (2006) Lead contamination and microbial lead tolerance in soils at major road junction in Benin City. J Appl Sci Environ Manag 10(2):99-104

Beyene H, Banerjee Sandip (2011) Assessment of the pollution status of the solid waste disposal sites of Addis Ababa City with some selected trace elements, Ethiopia. World Appl Sci J 14(7):1048-1057

Bradford GR, Chang AC, Page AL (1996) Background concentrations of trace and major element in California soils. Kearney Foundation special report, University of California, Riverside, pp 1-52

Bradl HB (2005) Heavy metals in the enviornment: origin, interaction and remediation. Elsevier Academis press, London

Cai J, Cao Y, Tan H, Wang Y, Luo J (2011) Fractionation and ecological risk of metals in urban river sediments in Zhongshan City, Pearl River Delta. J Environ Monit 13:2450-2456

CSA (2007) Population and housing census of Ethiopia: results for Oromia Region, vol. 1, Tables 2.1, 2.5, 3.4. Accessed 26 June 2013

David O, Sunday A (2012) Assessment of vehicular pollution of road side soils in Ota metropolis, Ogun State, Nigeria. Int J Civil Environ Eng 12(4):40-46

Edwards AL (1976) The correlation coefficient. In: Introduction to linear regression and correlation, chapter 4.W.H. Freeman and Company, San Francisco, pp 33-46

Endale T, Negussie M, Chandravanshi BS, Feleke Z (2012) Determination of the level of lead in the roadside soils of Addis Ababa, Ethiopia. SINET Ethiop J Sci 35(2):81-94

European Environment Agency (EEA) (2007) Progress in management of contaminated sites (CSI 015). EEA. Assessment Published July 2005; Kongen, ytorv,6DK-1050, Denmark. http://www.eea.europa.au

Ewers U (1991) Standard, guidelines and legislative regulations concerning metals and their compounds. In: Merian E (ed) Metals and their compounds in the environmental:occurrences, analysis and biological relevance. VCM, Weinheim, pp 458-468

FAO (1985) Water quality for agriculture. Irrig Drain 29(1):1-120

Hakanson L (1980) An ecological risk index for aquatic pollution control, a sedimentological approach. Water Res 14:975-1001
Hewitt CN, Rashed M (1988) Proceeding international conference chemical in the environment

Itanna F (2002) Metals in leafy vegetables grown in Addis Ababa and toxicological implications. Ethiop J Health Dev 16(3):295-302

Itanna F, Breuer J, Olsson M (2008) The fate and bioavialability of some trace elements applied to two vegetable farms in Ethiopia. African J Agric Res 3(11):797-807

Jaradat Q, Masadeh A, Zaitoun M, Maitah B (2005) Heavy metal contamination of soil, plant and air of scrapyard of discarded vehicles at Zarqa City, Jordan. Soil Sediment Contam 14:449-462

Jarup L, Akesson A (2009) Current status of cadmium as an environemntal health problem. Toxicol Appl Pharmacol 238(3):201-208

Jiang M, Zeng G, Zhang C, Ma X, Chen M, Zhang J, Lu L, Yu Q, Hu L, Liu L (2013) Assessment of heavy metal contamination in the surrounding soils and surface sediments in Xiawangang River, Qingshuitang District. PLoS One 8(8):e71176. doi:10.1371/journal.pone.0071176

Kadirvelu K, Thamaraisevi K, Namasivayama C (2001) Removal of heavy metal from industrial wastewaters by adsorption onto activated carbon prepared from an agricultural solid waste. Bioresour Technol 76:63-65

Komatsuzaki M, Ohta H (2007) Soil management practices for sustainable agro-ecosystems. Sustain Sci 2:103-120

Landrigan PJ (1994) Lead. In: Rosenstock L, Cullen MR (eds) Textbook of clinical occupational and environmental medicine. Saunders, Philadelphia, pp 745-754

Melaku S, Wondimu T, Dams R, Moens L (2005) Multi-element analysis of Tinushu Akaki River Sediment, Ethiopia, by ICP-MS after microwave assisted Digestion. Can J Anal Sci Spec 50:1

Muller G (1969) Index of geoaccumulation is sediments of the Rhine River. Geo J 2:108-118

Naser H, Sultana S, Mahmud N, Gomes R, Noor S (2011) Heavy metal levels in vegetables with growth stage and plant species variation. Bangladesh J Agric Res 36(4):563-574

Navarro M, Pérez-Sirvent C, Martínez-Sánchez M, Vidal J, Tovar P, Bech J (2008) Abandoned mine sites as a source of contamination by heavy metals: a case study in a semi-arid zone. J Geochem Explor 96(2-3):183-193

Needleman HL, Schell A, Bellinger D, Leviton A, Allred EN (1990) The long-term effect of exposure to low doses of lead in childhood. An 11 year follow up report. N Engl J Med 322:83-88

Ololade IA (2014) An Assessment of heavy metal contamination in soils within automechanical workshops using enrichment and contamination factors with geoaccumulation index. J Environ Prot 5:970-982. doi:10.4236/ jep.2014.511098

Olukanni DO, Adeoye DO (2012) Heavy metal concentrations in road side soils from selected location in the Lagos Metropolis, Nigeria. Int J Eng Technol 2(10):2049-3444

Shacklette HT, Boerngen JG (1984) Element concentration in soils and other surficial materials of the conterminous United States. US Geol Surv Prof Paper 1270:105

SWARDO (Shashemane Woreda Agriculture and Rural Development Office) (2006) Shashemane Woreda Agricuture and Rural Development Office, the Annual Report. Shashemane, Ethiopia

Syed RR, Dilara K, Tanveer MA, Mohammad SI, Mohammad AA, Mohammad AA (2012) Assessment of heavy metal contamination of agricultural soil around Dhaka export processing zone (DEPZ), Bangladesh: implication of Seasonal Variation and Indices. Appl Sci 2:584-601. doi:10.3390/ app2030584

Tamene FD (2008) Assessment of lead toxicity awareness among battery charging garage and workshop workers and levels of lead in piped drinking water of Addis Ababa, Ethiopia. http://etd.aau.edu.et/dspace/ items-by-author=Tamene\%2C+Fite

Tomlinson DL, Wilson JG, Harris CR, Dw Jeffrey (1980) Problems in the assessment of heavy metal level in estuaries and the formation of a pollution index. Helolaender Meesesunter 33:566-575

USEPA (1993) Guidelines for making enviromentally-sound decisions in the superfund remedial process. Region V Waste Management Division, Chicago, IL

Vaalgamaa S, Conley D (2008) Detecting environmental change in estuaries: nutrient and heavy metal distributions in sediment cores in estuaries from the Gulf of Finland, Baltic Sea. Estuar Coast Shelf Sci 76(1):45-56 